\title{
BANTUAN CHINA BERUPA ALAT UJI CEPAT COVID-19 KEPADA FILIPINA: PERSPEKTIF DIPLOMACY AND INTERNATIONAL LOBBYING THEORY
}

\author{
Hayatul Khairul Rahmat ${ }^{1}$, Rizkia Mutiara Ramadhani' ${ }^{2}$, Nurbaiti Ma'rufah ${ }^{3}$, \\ Fitri Andrianti Indah Gustaman ${ }^{4}$, Siswo Hadi Sumantri ${ }^{5}$, Agus Adriyanto ${ }^{6}$ \\ 1, 2, 3, 4 Program Studi Magister Manajemen Bencana, Universitas Pertahanan \\ 5 Program Studi Magister Keamanan Maritim, Universitas Pertahanan \\ ${ }^{6}$ Program Studi Magister Damai dan Resolusi Konflik, Universitas Pertahanan \\ e-mail: hayatul.rahmat@idu.ac.id
}

\begin{abstract}
This article aims to explain the objectives to be achieved by China related to the assistance give to the Philippines and the response that the Philippines should have done in responding. This paper used the literature study method with a descriptive approach. As for the findings of this paper, related to the theory of diplomacy and international lobbying, assistance provided by China to the Philippines is a tool used to achieve China's own interests and will have an influence on subsequent policy makers regarding maritime conflicts between China and the Philippines. Steps that needed to be taken by the Philippines are to maintain diplomatic relations with China, especially in the economic field because the Philippines economy is strongly supported by China and also strengthen its territorial defense and increase Philippine intelligence activities.
\end{abstract}

Keywords: covid-19, diplomacy, china, philippines

Received: 28 Maret 2020

Accepted: 25 April 2020

Published: 15 Juni 2020

\section{PENDAHULUAN}

Akhir tahun 2019, China digemparkan dengan serangan virus seperti pneumonia atau radang paru-paru. Detail virus penyebab infeksi, saat itu tidak diketahui dan para ahli penyakit di seluruh dunia mulai bekerja untuk mengidentifikasi virus tersebut. Setelah melakukan serangkaian investigasi, dugaan sumber virus pertama kali menyebar terlacak di pasar makanan laut di kota Wuhan (Welle, 2020). Kematian pertama akibat virus tersebut diumumkan China pada 11 Januari 2020 yaitu seorang pria berusia 61 tahun dengan diagnosa komplikasi yang disertai pneumonia. Sementara itu, di bulan yang sama para profesor China berhasil mengidentifikasi virus secara utuh dan hasilnya temuan menunjukkan virus Corona yang mirip dengan penyebab Severe Acute Respiratory Syndrome (SARS) (Zhu N et al., 2020). Pada awalnya virus tersebut dinamai 2019 $\mathrm{nCoV}$, namun setelah berbagai penelitian dilakukan, diketahui bahwa penyebab penyakit yang dilabeli sebagai COVID-19 adalah SARS Cov-2 (Weiss \& Murdoch, 2020). Beberapa laporan yang diterbitkan tentang deskripsi gejala klinis awal penyakit yaitu demam, batuk, kesulitan bernafas dan pneumonia (Mizumoto \& Chowell, 2020). 
China melakukan kebijakan untuk mengkarantina kota Wuhan pada 23 Januari 2020 dalam upaya membatasi penyebaran virus. Hanya berselang satu hari setelah keputusan karantina, jumlah pasien terinfeksi melonjak menjadi lebih dari 830 dengan angka kematian meningkat menjadi 26. Pemerintah akhirnya memperluas karantina hingga ke 13 kota lain (Welle, 2020). Semakin banyak kasus dikonfirmasi di luar China, termasuk di Korea Selatan, Amerika Serikat, Thailand, Hong Kong, Singapura, Malaysia, dan Taiwan. Namun, hingga 23 Januari 2020, World Health Organization belum menentukan pandemic. Kematian pertama terkait dengan COVID-19 di luar China dilaporkan terjadi di Filipina pada 2 Februari 2020. Seorang lelaki Tionghoa berusia 44 tahun telah melakukan perjalanan dari Wuhan ke Manila sebelum jatuh sakit dan dibawa ke rumah sakit, di mana ia kemudian meninggal karena pneumonia (Welle, 2020).

Angka pasien terjangkit COVID-19 di Filipina terus meningkat hingga 202 kasus, diiringi peningkatan angka kematian sejumlah 17 orang. Pada 15 Maret 2020, Filipina mulai menerapkan kebijakan untuk membatasi pergerakan orang di wilayah tersebut sebagai upaya untuk mencegah penyebaran virus. Selain itu, pemerintah Filipina mengumumkan pembatasan perjalanan untuk semua warga negara yang datang dari negara-negara yang dilaporkan terjadi transmisi lokal COVID-19 (The Star, 2020). Dalam media Inggris The Star (2020), Huang Xilian, Duta Besar China untuk Filipina mengatakan bahwa China akan melakukan yang terbaik untuk membantu Filipina dalam menghadapi penyebaran COVID-19 di negara tersebut. Xilian menyatakan batch pertama kit uji COVID-19 yang dihibahkan dari pemerintah China akan diberikan dan sedang dalam perjalanan menuju Filipina. Anggota Dewan Negara China dan Menteri Luar Negeri Wang Yi mengatakan bahwa China bersedia melakukan segala hal yang terbaik untuk membantu Filipina dalam memerangi COVID-19. Mengingat bahwa Filipina ada dalam masa sulit dalam upaya penanganan pandemi COVID-19, maka bantuan yang akan secara aktif diberikan pemerintah China berupa fasilitas medis. Namun, China akan mempertimbangkan juga pengiriman bantuan para ahli medis ke Filipina (The Star, 2020).

Interaksi antara China dan Filipina melalui rencana bantuan medis sekilas terlihat sebagai hubungan karib antar negara. Padahal sebelumnya terjadi konflik antara kedua negara tersebut yang berkaitan dengan batas wilayah laut di kawasan laut China Selatan. Konflik terjadi karena China mengklaim hak bersejarah wilayah sembilan titik garis batas putus-putus atau nine dash line dengan luas 2 juta $\mathrm{km}^{2}$ di Laut China Selatan sebagai wilayah China. Hal tersebut sekaligus berarti $80 \%$ laut Filipina diakui sebagai wilayah milik China (Permana, 2020). Dengan adanya pengakuan dari China tersebut Filipina mengajukan gugatan ke Pengadilan Arbitrase Tetap Internasional yang berada di bawah Perserikatan Bangsa-Bangsa. Hasil putusan pengadilan yaitu pengakuan wilayah Laut China Selatan yang dinyatakan China tidak memiliki dasar hukum, tidak ada bukti sejarah yang menjelaskan bahwa sumber daya di Laut China Selatan secara eksklusif dapat dikuasai dan dikendalikan oleh China. Selain itu, pengadilan memutuskan bahwa China telah melanggar hak-hak kedaulatan Filipina dengan bukti adanya kerusakan lingkungan yang terjadi pada terumbu karang (PCA, 2016). Disisi lain, China menyatakan tidak akan menerima, mengakui dan melaksanakan hasil keputusan Pengadilan Arbitrase bahkan tidak mengakui 
keberadaan Mahkamah Arbitrase karena dianggap tidak memiliki yuridiksi (Darajati, Adolf \& Idris, 2018).

Merujuk pada dua kenyataan yang berbeda antara konflik batas wilayah laut yang terjadi sebelum adanya rencana bantuan China ke Filipina, keduanya merupakan peristiwa yang bertolak belakang. Sudut pandang diplomasi dan lobi internasional memandang keputusan China dalam memberikan bantuan medis kepada Filipina merupakan kebijakan China yang berpotensi memiliki tujuan atau kepentingan negara, tidak semata-mata sebagai bentuk bantuan saja. Untuk membuktikan hal tersebut, maka perlu adanya kajian mengenai tujuan yang ingin dicapai oleh China terkait dua fenomena di atas dan respon yang seharusnya dilakukan Filipina dalam menyikapi kejadian tersebut. Dengan demikian, dalam tulisan ini, penulis akan menitikberatkan pada kedua bahasan yang telah diuraikan.

\section{METODE PENELITIAN}

Dalam penyusunan naskah ini menggunakan metode penelitian kepustakaan (library research) yaitu mengumpulkan semua bahan bacaan yang berkaitan dengan masalah yang dibahas, kemudian memahami secara teliti dan hati-hati sehingga menghasilkan temuan-temuan penelitian. Sebagai pendukung dalam penelitian ini, maka penulis melakukan kegiatan studi literatur yang mendalam yaitu dengan menggunakan penulisan deskriptif. Data yang dikumpulkan dalam penulisan ini adalah data-data sekunder yang berasal dari studi keputakaan dan studi dokumentasi. Metode analisis yang digunakan adalah deskriptif kualitatif.

\section{HASIL PENELITIAN DAN PEMBAHASAN}

\section{Bantuan Alat Uji Cepat Covid-19 dari China kepada Filipina dalam Teori Diplomasi dan Lobi Internasional}

Diplomasi adalah instrumen penting dalam pelaksanaan kepentingan nasional suatu negara. Diplomasi sebagai alat utama dalam pencapaian kepentingan nasional yang berhubungan dengan negara lain atau organisasi internasional. Pelaksanaan diplomasi ini dapat membangun citra sebuah negara. Dalam hubungan antar negara, biasanya diplomasi diterapkan sejak tingkat paling awal sebuah negara hendak melakukan hubungan bilateral dengan negara lain sampai keduanya mengembangkan hubungan selanjutnya (Nurika, 2017). Menurut Berridge (2010), konsep diplomasi merujuk pada aktivitas politik yang dilakukan oleh para aktor untuk mengejar tujuannya dan mempertahankan kepentingannya melalui negosiasi, tanpa menggunakan kekerasan, propaganda, atau hukum. Diplomasi terdiri dari komunikasi antar sejumlah pihak yang didesain untuk mencapai kesepakatan. Selain itu, dalam hubungannya dengan politik internasional, diplomasi adalah seni mengedepankan kepentingan suatu negara dalam hubungannya dengan negara lain. Diplomasi juga dapat diartikan sebagai penerapan kepandaian dan taktik pada pelaksanaan hubungan resmi antar pemerintah negara-negara berdaulat.

Tidak jauh berbeda dengan diplomasi, aktivitas lobi juga berkaitan erat dengan aktifitas politik luar negeri. Aktivitas lobi pada intinya adalah sebuah fenomena gunung es yang terjadi antara pemerintah dengan kelompok kepentingan untuk mencapai suatu tujuan tertentu (Fawcett, 2005). Secara teori, 
kelompok lobi termasuk ke dalam kelompok kepentingan. Adapun gerak dan aktivitas kelompok lobi merupakan usaha untuk menyeleraskan kepentingan kelompok serta kebijakan pemerintah. Kelompok lobi adalah suatu diaspora yang berada di luar sistem perumusan kebijakan luar negeri dan bersifat tidak formal. Untuk mendapat kepentingan melalui sebuah legalitas dan legitimasi, kelompok kepentingan harus menyeleraskan visi misi mereka dengan kebijakan pemerintah atau bila memungkinkan dapat tumpang tindih (overlap) (Ramadhan, 2017).

Dalam tulisan ini, bantuan alat uji cepat Covid-19 kepada Filipina dapat dianggap sebagai salah satu bentuk diplomasi ataupun aktivitas lobi yang dilakukan oleh China. Sebelumnya, China dan Filipina telah lama berselisih tentang batas wilayah laut hingga akhirnya dibawa ke Mahkamah Internasional. Pemberian bantuan dua ribu alat uji cepat untuk virus corona tipe baru dapat membentuk opini hingga mempengaruhi para pengambil kebijakan. Secara deskriptif, dampak dari lobi akan dapat terlihat secara nyata maupun tidak. Hal ini dikhawatirkan akan menimbulkan kebijakan yang berstandar ganda dikarenakan keputusan yang diambil perumusan kebijakan akan berseberangan dengan kepentingan nasional ataupun norma dan hukum internasional yang berlaku.

\section{Kepentingan China terhadap Bantuan Alat Uji Cepat Covid-19 kepada Filipina}

Perselisihan kompleks di Laut China Selatan yang melibatkan banyak negara, salah satunya Filipina merupakan masalah yang pelik karena memiliki sejarah yang panjang. Asal usul sengketa wilayah dimulai sejak maraknya kolonialisme Eropa dan Jepang hingga diperparah karena konflik pasca-Perang Dunia II di Asia Tenggara. China telah mengeluarkan peta garis putus-putus atau nine dash line yang jelas ambigu. Sejak diterbitkannya peta tersebut, China mulai mengambil langkah untuk membela apa yang digambarkannya sebagai haknya di laut.

Bisley (2016) berpendapat ada tiga hal utama yang tampaknya dicari oleh China. Pertama, laut dianggap kaya akan minyak dan gas. China tidak hanya menginginkan manfaat ekonomi yang berasal dari hak berdaulat atas cadangan hidrokarbon saja, tetapi juga keamanan pasokan kekayaan sumber daya lain yang diperlukan. China juga menginginkan keamanan melalui pendekatan maritimnya. Negara ini bergantung pada kemakmuran ekonominya pada arus perdagangan energi dan komoditas yang masuk dan barang jadi yang akan dipasarkan. Namun, perdagangan tersebut seringkali menemui kendala pada perlindungan aset di jalur pelayaran, mengingat banyak negara yang saat ini memiliki kedaulatan di Laut China Selatan. Kepentingan nasional yang paling utama, Negara berargumen bahwa laut merupakan wilayah penting dengan historis kejayaan China di masa lalu.

Pada sengketa Laut China Selatan yang melibatkan China dan Filipina, Mahkamah Arbitrase telah memutuskan bahwa bukti historis kepemilikian China akan kedaulatannya di Laut China Selatan tidak ditemukan sehingga klaim tersebut tidak memiliki dasar hukum (Megawati \& Arundhati, 2018). Tidak sampai disitu, pengadilan bahkan memutuskan bahwa terjadi pelanggaran yang dilakukan China terhadap hak-hak kedaulatan Filipina di kawasan Laut China Selatan. Hal tersebut dibuktikan oleh adanya kerusakan lingkungan yang terjadi. Putusan Mahkamah Arbitrase didasari oleh Konvensi PBB tentang Hukum Laut (UNCLOS) 
yang ditandatangani pemerintah Filipina dan China. Keputusan Mahkamah Arbitrase sekaligus mengisyaratkan kemenangan Filipina atas China perihal segketa Laut China Selatan (Beckman, 2015) (Hayton, 2018).

China sebagai negara yang kalah dalam persidangan, tentu tidak menerima hasil putusan tersebut dan akan mengabaikan dan tidak akan melakukan hasil putusan yang diberikan. Bahkan, China malah beranggapan Mahkamah Arbitrase tidak dapat diakui karena tidak memiliki yuridiksi (Zhang, 2017). Keputusan Mahkamah Arbitrase yang didasari dengan UNCLOS sebenarnya bersifat mengikat, namun Mahkamah tidak memiliki kekuatan untuk menerapkannya. Konflik yang telah terjadi antar kedua negara tersebut tentu masih teringat dalam memori. Konflik biasanya menyisakan hubungan yang tidak harmonis bahkan bisa berpotensi menimbulkan perselisihan berikutnya (Zhang, 2019). Namun, saat ini, kedua negara justru terlihat rukun seperti kakak yang sedang membantu meringankan beban adiknya. Baru-baru ini China menawarkan bantuan medis berupa kit pemeriksaan dan fasilitas medis lainnya sebagai dorongan kepada Filipina dalam menyelesaikan permasalahan COVID-19. Tidak sampai disitu, bahkan China mempertimbangkan pengiriman bantuan petugas medis untuk membantu perawatan pasien COVID-19 di Filipina (The Star, 2020).

Dari sisi kemanusiaan, hal ini akan dimaknai sebagai kebijakan yang murni ditujukan untuk membantu meringankan dan menyelamatkan nyawa warga Filipina yang terancam serangan virus SARS Cov 2. Tetapi, dari sudut pandang diplomasi dan lobi internasional, tidak menutup kemungkinan bahwa kebijakan China dalam membantu Filipina adalah upaya diplomasi yang ditempuh untuk melunakan Filipina dan memperoleh dukungan dalam pencapaian kepentingan nasional China (Trinidad, 2019). Berdasarkan berbagai teori kepentingan nasional yang sebelumnya telah diuraikan, kepentingan nasional bergantung pada kepentingan negara yang bertujuan untuk memperoleh keamanan dan stabilitas ekonomi.

Kepentingan nasional China di Laut China Selatan merupakan kepentingan yang selama ini seolah-olah dominan ingin diwujudkan. Mayoritas pejabat pemerintahan China nampak berambisi dalam menguasai kawasan Laut China Selatan sesuai yang disajikan dalam peta nine dash line. Merujuk pada teori kepentingan nasional dari konstruktivisme, kondisi masyarakat internasional akan membangun kepentingan nasional suatu negara. Dengan demikian, bantuan China kepada Filipina memiliki potensi sebagai upaya dalam merealisasikan kepentingan nasional China mengenai wilayah Laut China Selatan yang sebelumnya terhambat karena penolakan Filipina. Penulis berpandangan bahwa, dengan kebijakan yang dilakukan saat ini, China berharap bahwa Filipina akan lebih luna dalam menyikapi sengketa Laut China Selatan dan memberikan kemudahan bagi China dalam melancarkan visi dan misinya.

\section{Langkah Filipina Terkait Bantuan yang Diberikan Oleh China Berupa Alat Uji Cepat Covid-19}

Pada Senin, 16 Maret 2020, China menyumbangkan dua ribu alat uji cepat untuk virus corona tipe baru Covid-19 kepada Filipina dengan tujuan membantu Filipina menangani pandemik corona (Syahrianto, 2020). Bantuan alat uji cepat ini datang saat Filipina sedang menyaksikan peningkatan jumlah kasus Covid-19 
dalam beberapa hari terakhir. Saat ini, terdapat 140 kasus yang terkonfirmasi di Filipina dengan jumlah kematian sebanyak 12 jiwa. Pada Minggu, 15 Maret 2020, Menteri Luar Negeri China Wang Yi melakukan percakapan via telepon dengan Menteri Luar Negeri Filipina Teodoro Locsin dan memberikan ucapan terima kasih kepada Filipina telah mendukung China saat penyebaran Covid-19 masih sangat tinggi (Dikarma, 2020). Bantuan yang diberikan oleh China kepada Filipina dalam politik internasional sebagai sebuah langkah untuk menjaga hubungan diplomatik antara kedua negara. Hubungan diplomatik antara China dan Filipina sudah dimulai sejak tanggal 9 Juni 1975 dengan penandatangan The Joint Communique oleh kedua pimpinan negara tersebut (Flick \& Kemburi, 2012). Semenjak itu, kemitraan bilateral kedua negara tersebut mencapai tingkat perdagangan, investasi, pertanian, pariwisata, budaya, dan masyarakat.

Filipina percaya bahwa kontrol China terhadap Mischief Reef dan terumbu karang lainnya setelah akhir 1990-an merupakan ancaman bagi keamanan nasionalnya (Hong, 2012). Walau demikian, semenjak tahun 1993 antara Presiden Filipina Ramos dan Presiden China Jiang Zemin setuju pada prinsipnya untuk mengeksplorasi dan mengembangkan wilayah sengketa secara bersama-sama dan mengesampingkan isu kedaulatan (Jie, 1994). Secara komprehensif, hubungan China dan Filipina dari tahun 1975-2010 melihat penandatanganan 100 perjanjian bilateral mulai dari bidang politik, pertahanan, perdagangan, investasi, hukum, pembangunan infrastruktur, kerjasama energi, jasa angkutan udara, penanganan kejahatan transnasional, turis pariwisata, budaya, olahraga, pertukaran media, sains dan teknologi, kota saudara, konsultasi militer, dan sebagainya (Tuazon, 2014). Pasca putusan Permanent Court of Arbitration 2016 yang memenangkan Filipina atas klaim di Laut China Selatan dan menolak China atas klaim historisnya berupa nine dash line di Laut China Selatan. Semenjak itu, terjadi perubahan kebijakan politik luar negeri Filipina dari masa Benigno Aquino III (2010-2016) dengan Presiden Rodrigo Duterte yang mulai menjabat pada Juni 2016. Semenjak itu, Filipina dibawah Aquino mengeluarkan kebijakan yang telah menyeimbangkan klaim maritim China di Laut China Selatan. Kemudian mengalihkan fokus Armed Forces of the Philippines (AFP) dari keamanan dalam negeri menuju pertahanan territorial (David \& Taliaferro, 2019). Dalam hal ini terus memperkuat hubungan keamanan dengan Amerika Serikat dan mengakuisi peralatan militer Amerika Serikat (Jemadu. 2008). Masa Presiden Rodrigo Duterte mengesampingkan hasil PCA 2016 demi mengendalikan ekonominya dan terus bekerjasama dengan China dan inilah dinamika kebijakan luar negeri Filipina terhadap China.

Jika dikaitkan dengan bantuan yang diberikan oleh China kepada Filipina berupa alat uji cepat virus corona tipe baru yang disebut Covid-19, maka langkah yang perlu dilakukan oleh Filipina yaitu tetap menjaga hubungan diplomatik dengan China terutama dalam bidang ekonomi dikarenakan ekonomi Filipina sangatlah disokong oleh China. Walau demikian, sebelumnya diketahui bahwa selama ini Filipina adalah kuda troya Amerika Serikat di Asia Tenggara (Penzenstadler, 2016). Sementara saat ini, kebijakan luar negeri Duterte yang ingin independen atau bebas tidak dibawah satu blok manapun, baik itu Amerika Serikat maupun China (Hendle, 2018). Oleh karena itu, perlu langkah dari Filipina yaitu memperkuat pertahanan teritorialnya dan meningkatkan kegiatan intelijen Filipina terkait bantuan yang diberikan oleh China tersebut walaupun itu bantuan 
untuk menjaga hubungan diplomatik antara kedua negara. Hal ini tentu sejalan dengan kebijakan Duterte dimana mengabaikan hasil PCA 2016 dan terus mengembangkan perekonomian Filipina dan tidak lagi menjadi kuda troya Amerika Serikat.

\section{KESIMPULAN}

Berdasarkan uraian di atas, adapun kesimpulan dari penulisan ini adalah: Pertama, dihubungkan dengan teori diplomasi dan lobi internasional, bantuan yang diberikan China kepada Filipina merupakan alat yang digunakan untuk mencapai kepentingan China itu sendiri. Maraknya segala pemberitaan terkait Covid-19, termasuk pemberian bantuan yang terekspose dapat menggiring opini publik. Begitu pula opini terhadap China, hal ini dikhawatirkan akan memberi pengaruh terhadap pengambil kebijakan berikutnya terkait konflik maritim antara China dan Filipina

Kedua, dikaitkan teori kepentingan nasional, kebijakan China dalam membantu Filipina untuk menghadapi COVID-19 tidak semata-mata dilakukan untuk kemanuasiaan saja. Hal tersebut mengingat sebelumnya terdapat konflik batas wilayah laut yang melibatkan Filipina dan China di Laut China Selatan. Nine dash line di wilayah Laut China Selatan merupakan ambisi wilayah kekuasaan China karena diklaim lekat dengan historis negara China. Ketiga, jika dikaitkan dengan bantuan yang diberikan oleh China kepada Filipina berupa alat uji cepat virus corona tipe baru yang disebut Covid-19, maka langkah yang perlu dilakukan oleh Filipina yaitu tetap menjaga hubungan diplomatik dengan China terutama dalam bidang ekonomi dikarenakan ekonomi Filipina sangatlah disokong oleh China. Bantuan yang diberikan oleh China ini juga perlu diantisipasi dengan memperkuat pertahanan teritorialnya dan meningkatkan kegiatan intelijen Filipina dan itu sejalan dengan kebijakan Duterte dimana mengabaikan hasil PCA 2016 dan terus mengembangkan perekonomian Filipina dan tidak lagi menjadi kuda troya Amerika Serikat.

\section{DAFTAR PUSTAKA}

Beckman, R.C. 2015. The Philippines V. China Chase and the South China Disputes. Territorial Disputes in the South China Sea. Eds. Huang J. \& Billo A. London: Palgrave Macmillan.

Berridge, G. R. 2010. Diplomacy: Theory and Practice. New York: Palgrave.

Bisley, N. 2016. What Does China Actually Want in the South China Sea. Retrieved from https://nationalinterest.org/feature/what-does-china-actually-wantthe-south-china-sea-18211, diakses tanggal 18 Maret 2020.

Darajati, M.R., Adolf, H., \& Idris, I. 2018. Putusan Sengketa Laut China Selatan serta Implikasi Hukumnya terhadap Negara di Sekitar Kawasan Tersebut. Jurnal Hukum \& Pembangunan, 48 (1). 
David, S.V.T. \& Taliaferro, A.C. 2019. Implementing the Philippine Defense Reform Program in Partnership with US Department of Defense Support of Philippine Defense Institutions. Journal of Indo-Pacivic Affairs Summer, 0 (0), 17-41.

Dikarma, K. 2020. China Sumbang Dua Ribu Alat Uji Corona untuk Filipina. Retrieved from http://m.republik.co.id/amp/q7a2od459, diakses tanggal 18 Maret 2020.

Fawcett, L. 2005. International Relations of the Middle East. New York: Oxford Press.

Flick, K. E. \& Kemburi, K. M. 2012. ASEAN-China Free Trade Area: Challenges, Opportunities, and the Road Ahead. Singapore: S. Rajaratnam School of Internasional Studies.

Hayton, B. 2018. The Modern Creation of China's 'Historic Rights' Claim in the South China Sea. Asian Affairs, 49 (3).

Hendle, B. 2018. Duterte's Pivot to China and Prospects for Settling the South China Sea Disputes. Contexto International, 40 (2).

Hong, Z. 2012. Sino-Philippines Relations: Moving Beyond South China Sea Dispute? The Journal of East Asian Affair, 26 (2), 57-76.

Jemadu, A. 2008. Politik Global dalam Teori dan Praktik. Yogyakarta: Graha Ilmu.

Jie, C. 1994. China's spratly Policy? With Special Reference to the Philippines and Malaysia. Asian Survey, 34 (10), 893-903.

Mearsheimer, J. \& Walt, S. 2008. The Israel Lobby and U.S Foreign Policy. New York: Farrar, Stars and Giroux.

Megawati, A. \& Arundhati, G.B. 2018. Dinamika Sikap Tiongkok atas Putusan Mahkamah Arbitrase Tetap Internasional Nomor 2013-19 dan Pengaruhnya terhadap Indonesia. Lentera Hukum, 5 (1).

Mizumoto, K. \& Chowell, G. 2020. Estimating Risk for Death from 2019 Novel Coronavirus Disease, China, January-February 2020. Emerging Infectious Diseases, 26 (5), 264-270.

Na Zhu, Zhang, D., \& Wang, W. 2019. A Novel Coronavirus from Patients with Pneumonia in China. New England Journal of Medicine, 382, 727-733.

Nurika, R. R. 2017. Peran Globalisasi di Balik Munculnya Tantangan Baru bagi Diplomasi di Era Kontemporer. Jurnal Sospol, 3 (1), 126-141. 
PCA. 2016. The South China Sea Arbitration (the Republic of Philippines-the People's Republic of China). Netherlands: Peace Palace.

Penzestadler, N. 2016. Philippines Duterte to U.S. Over Aid Bye-bye America. Retrieved from http://www.usatoday.com/story/news/world/2016/12/17/philippinesduterte-us-over-aid-bye-bye-america/95557384/, diakses tanggal 18 Maret 2020.

Permana, R. H. 2020. Putusan Pengadilan Arbitrase PBB: China Tak Berhak atas Laut Natuna. Retrieved from https://news.detik.com/berita/d4848514/putusan-pengadilan-arbitrase-pbb-china-tak-berhak-atas-lautnatuna, diakses tanggal 18 Maret 2020.

Ramadhan, I. 2017. Lobi Israel dalam Kebijakan Luar Negeri Amerika Serikat ke Timur Tengah. Intermestic: Journal of International Studies, 1 (2), 144-165.

Syahrianto, M. 2020. Dermawan Banget! Filipina Dapat Sumbangan 2.000 Alat Uji Corona dari China. Retrieved from http://www.wartaekonomi.co.id/berita276714/dermawan-banget-filipinadapat-sumbangan-2000-alat-uji-corona-dari-cina, diakses tanggal 18 Maret 2020.

The Star. 2020. Covid-19: China Ready to Send Aid to the Philippines. Retrieved from https://www.thestar.com.my/news/regional/2020/03/16/covid-19-chinaready-to-send-aid-to-the-philippines, diakses tanggal 18 Maret 2020.

Trinidad, D. 2019. Strategic Foreign Aid Competition: Japanese and Chinese Assistance in the Philippine Infrastructure Sector. Asian Affairs: An American Review, 46 (4).

Tuazon, B. M. 2012. The High and Lows of Philippines-China Relations: Current Situation and Prospects. China: Institute of Southeast Asian Studies Guangxi Academy of Social Science.

Weiss, P \& Murdoch, D. R. 2020. Clinical Course and Mortality Risk of Severe Covid19. The Lancet, doi: 10.1016/S0140-6736(20)30633-4.

Welle, D. 2020. Coronavirus: Timeline of the Global Spread of Covid-19. Retrieved from https://www.dw.com/en/coronavirus-timeline-of-the-global-spreadof-covid-19/g-52145412, diakses tanggal 18 Maret 2020.

Zhang, F. 2017. Assessing China's Response to the South China Sea Arbitration Ruling. Australian Journal of International Affairs, 71 (4).

Zhang, F. 2019. China's Long March at Sea: Explaining Beijings' South China Sea Strategy, 2009-2016. The Pacivic Review, 0 (0), 1-31. 